Philip Sutherland, SJ

Boston College

School of Theology and Ministry

\title{
Girard and the Millennials: New Perspectives on Evangelization
}

\begin{abstract}
René Girard in conversation with Charles Taylor can help us to analyze the connection between violence and religion. Girard's lens of mimetic desire helps to clarify how Jesus was the anti-sacrifice who desired to end the scapegoat mechanism. Taylor provides a lens on the transcendent and its sometimes hidden presence in our secular world. People are constantly feeling the cross pressures between a closed immanent frame and an openness to fulfillment outside of one's self. Taylor's analysis becomes concrete in the sociological research regarding Millennials and their ambivalence toward organized religion. Many young adults today are seeking the transcendent but have no idea how to find it. Additionally, they are wary of the divisiveness of religion and many view religion as but another contributor to an already violent world. However, Boeve's image of theology as interruption gives us a lens with which to see Girard's narrative as God's interruption of human history. This interruption demands an equally serious, committed response. Such a demanding and meaningful narrative can be attractive to Millennials who generally view religion as simply one equally meaningless choice among others.
\end{abstract}

\section{Introduction}

Current research of the American religious scene and of American Millennials reveals some important trends that are worth exploring if religion is to appeal to young adults today. One such avenue is the connection between religion and violence, a phenomenon often identified by younger Americans as one reason why they are generally wary of organized religion. A renewed emphasis on the gospels' anti-scapegoat mechanism as identified by René Girard provides one way to present Christianity as an important and attractive option for young people today.

Girard in conversation with Charles Taylor can help us to analyze the connection between violence and religion. Girard's lens of mimetic desire helps to clarify how Jesus was the anti-sacrifice who desired to end the scapegoat mechanism. Taylor provides a lens on the transcendent and its sometimes hidden presence in our secular world. People are constantly feeling the cross pressures between a closed immanent frame and an openness to fulfillment outside of one's self. Taylor's analysis becomes concrete in the sociological research regarding 
Millennials and their ambivalence toward organized religion. Many young adults today are seeking the transcendent but have no idea how to find it. Additionally, they are wary of the divisiveness of religion and many view religion as but another contributor to an already violent world. However, Lieven Boeve's image of theology as interruption gives us a lens with which to see Girard's narrative as God's interruption of human history, of humanity's narrative. This interruption demands an equally serious, committed response. Such a demanding and meaningful narrative can be attractive to Millennials who generally view religion as simply one equally meaningless choice among others.

\section{Girard and Mimetic Violence}

In his study of the mythologies of different cultures, Girard was one of the first anthropologists to realize that all of the cultures he studied possessed myths that involved violence, sacrifice and "mimetic desire." In his study of literature in Deceit, Desire, and the Novel he advanced his thesis of the "imitative character of human desire." Girard's anthropology focused mainly on the concept of desire, specifically desire as a result of imitation of another person's desire, as the basis of all culture. ${ }^{2}$ Although Girard was a pioneer in this field, the empirical sciences would later support Girard's basic insight through the discovery of mirror neurons as a neurological foundation of imitation in apes and humans. ${ }^{3}$ Such imitation

\footnotetext{
${ }^{1}$ Frederiek Depoortere, Christ in Postmodern Philosophy Gianni Vattimo, René Girard and Slavoj Žižek (London: T \& T Clark, 2008), 34.

${ }^{2}$ René Girard, Things Hidden since the Foundation of the World, trans. Stephen Bann and Michael Metteer (Stanford, Calif.: Stanford University Press, 1987), 7.

${ }^{3}$ Depoortere, 65.
} 
probably played a key role in the development of language, brain size and culture in human evolution. 4

"Mimetic desire" is always a triangulation between an object of desire, a rival who desires the object and the subject who imitates the rival's desire. The subject is always one who "desires the object because the rival desires it." Thus, it is not a situation of the coincidence of two people desiring the same object, but rather a result of the desire of an object eliciting the same desire in another. The subject imitates the desire of the rival. But the rival blocks the subject's acquisition of the object and this mimetic competition can eventually result in violence. This connection between violence and desire is also at the base of all human cultures.

But this competition of desire is not merely for an object, for Girard describes the human person as lacking being and thus desiring to obtain the being possessed by another. ${ }^{6}$ If the mimetic rival, who already possesses superior being, desires an object, then the subject concludes the object must be capable of giving the rival an "even greater plenitude of being.", Thus, the subject desires the object not for its own sake, but as a means to achieve a greater plenitude of being than even the rival. ${ }^{8}$ Thus, the desired object achieves a "metaphysical status" in the mind of the subject, and even if the subject does succeed in acquiring the object—which of course is merely an ordinary object — he cannot admit to himself the "absurdity of the triangular desire" and must seek a new object or a new rival. ${ }^{9}$ Ultimately a subject may eventually find an

\footnotetext{
${ }^{4}$ Ibid., 66-75.

${ }^{5}$ René Girard, Violence and the Sacred, trans. Patrick Gregory (Baltimore: Johns Hopkins University Press, 1977), 145.

${ }^{6}$ Depoortere, 37.

${ }^{7}$ Girard, Violence and the Sacred, 146.

${ }^{8}$ Depoortere, 37.

${ }^{9}$ Depoortere, 38 Girard, Things Hidden Since the Foundation of the World, 88-89.
} 
object that is completely inaccessible in order to save his or her desire and protect him or herself from more disillusionment. ${ }^{10}$

At this point it is helpful to examine what Charles Taylor says about the immanent frame and cross pressures in order to connect the very natural, human desire for transcendence with sacred violence. Taylor theorizes that after the Enlightenment, the north Atlantic cultures now share an experience of an "immanent frame," an experience of a "'natural' or 'this-worldly" order which can be understood in its own terms, without reference to the 'supernatural' or 'transcendent.", 11 However, in addition to a decline in religious faith, there also exists the "fragilization" of different religious perspectives . ${ }^{12}$ This "fragilization" is the result of doubt and the awareness of alternatives to faith, particularly of those narratives that exclude any notion of transcendence. ${ }^{13}$ However, between the two extremes of religious faith and a closed immanent frame lie many middle positions. These positions become occupied by people who experience the "cross pressures" in modern society that hint at a transcendent aspect to reality. As Taylor notes, these cross pressures are the result of a myriad of experiences, including encounters with the existing "milieu of religious practice" or merely by some "intimations of the transcendent.",14 Thus, theists and atheists alike feel the cross pressures and must wrestle with at least the intellectual possibility of a transcendent aspect to their lives. These existential dilemmas (as Taylor calls them) are natural and hint at the inadequacy of an "immanent frame" that encloses and constricts one's experiences. Transcendence is a normal aspect of human experience that even the post-Enlightenment cultural shifts cannot completely conceal.

\footnotetext{
${ }^{10}$ Ibid., 39.

${ }^{11}$ Charles Taylor, A Secular Age (Cambridge, Mass.: Belknap Press of Harvard University Press, $2007,594$.

12 Ibid, 595.

13 Taylor, 595.

${ }^{14}$ Ibid., 595.
} 
Girard provides in his anthropology a systematic articulation of what Taylor is gesturing toward in his philosophical analysis when he proceeds to connect violence to the sacred. While most animals possess a natural "braking mechanism" on the mimetic competition before it can turn into uncontrolled violence, human beings must rely upon the rituals and taboos of culture to halt the escalation of mimetic competition. ${ }^{15}$ This "imperative of prohibition" plays itself out in the religious rituals designed to prevent violence by killing (sacrificing) a victim. ${ }^{16}$ Rather than letting the mimetic rivalry destroy a community, the group's collective violence against a single victim actually relieves the stress of the mimetic rivalry and preserves the community, at least for a time. However, this "scapegoat" - a reference to the goat in Lev. 16:21 that would bear the sins of the Israelites and be exiled into the wilderness - became a supernatural being in ancient cultures because the community also associated the victim with the peace experienced after the sacrifice ${ }^{17}$ In a pre-reflective, pre-critical manner, the gods of mythology were born from this scapegoat mechanism. ${ }^{18}$

Even though the origins of religion and culture are hidden, they do not disappear and are foundational to every culture. It is for this reason that Taylor states that the "sources of categorical violence are metaphysical rather than biological," for ultimately all violence has its roots in the sacred violence that arose from mimetic rivalry. ${ }^{19}$ Even post-axial religions such as Christianity which abandoned a sacrificial system have still repeated the cycle of the scapegoat mechanism through the persecution of, for example, heretics, Jews and Muslims. ${ }^{20}$ Thus, sacred violence is also a gesturing toward transcendence, which Taylor defines as "the supernatural...be

\footnotetext{
${ }^{15}$ Girard, Things Hidden Since the Foundation of the World, 28; Depoortere, 43.

${ }^{16}$ Girard, Things Hidden since the Foundation of the World, 28.

${ }^{17}$ Depoortere, 42.

${ }^{18}$ James G. Williams, Introduction in René Girard, I See Satan Fall Like Lightning, trans. James G. Williams (New York: Orbis Books, 2001), xvi.

${ }^{19}$ Taylor, 685.

${ }^{20}$ Ibid., 686.
} 
this understood in terms of the one transcendent God, or of Gods or spirits, or magic forces, or whatever. ${ }^{, 21}$ In the case of early mimetic rivalry, transcendence was toward the fulfillment of being which was located in the desired object (but always eluded acquisition). Later, as violence became tied to the sacred and the divine, transcendence was located in gods and spiritual forces. However, as Taylor notes, post-Enlightenment society has tried to replace much of the traditional scapegoat mechanism with other moral sources of social harmony such as altruism, solidarity and the enlightened self-interest of modern capitalism. ${ }^{22}$ With the rise of secularism came an attendant shift to an exclusive humanism that focused solely upon this-worldly human flourishing. Yet the transcendent still sneaks into human experience when people ask the metaquestion, what is the meaning of it all ${ }^{23}$ This is particularly true in the face of seemingly senseless violence.

Even the advent of a globalized market economy that can divert much of the mimetic rivalry toward economic competition, and with the attendant rise of democracies and a belief in the dignity of the human person that can suppress much of that violence, the scapegoat mechanism is still alive and well. ${ }^{24}$ But instead of victimizing innocent people, societies now feel morally justified in persecuting those who persecute innocent people: "you have to prove that your opponent is a persecutor in order to justify your own desire to persecute. ${ }^{25}$ However, Girard asserts that Jesus is the innocent victim who unmasks the scapegoat mechanism at the foundation of all cultures. $^{26}$

\footnotetext{
${ }^{21}$ Ibid., 16

${ }^{22}$ Ibid., 703.

${ }^{23}$ Ibid., 677.

${ }^{24}$ Joao Cezar de Castro Rocha, Pierpaolo Antonello and René Girard, Evolution and Conversion : Dialogues on the Origins of Culture (New York: Continuum International Publishing, 2007), 244.

${ }^{25}$ Ibid., 258.

${ }^{26}$ Girard, Things Hidden since the Foundation of the World, 210-211.
} 
Jesus' message of the Kingdom of God is about stopping the cycle of scapegoating and violence by renouncing vengeance, even in the face of unjust persecution. ${ }^{27}$ The Bible was unique in the literature of the ancient world in that it always sided with the victim rather than the persecutor. The Gospels fulfilled the desacralization of violence begun in the Hebrew scriptures, particularly by purging God of all violence through its identification of God as love and the many parables in which violence is not ascribed to God. ${ }^{28}$ As the Lamb of God risen from the dead, the Gospels clearly portray Jesus as the innocent victim who subverts the mechanisms of violence that have operated throughout human history. ${ }^{29}$ Girard sees this portrayal of Jesus as the innocent victim as proof of his divine status because the truth of violence could only be revealed by somebody who was not already held captive by it. ${ }^{30}$

But Girard sees a deep irony in the way the Christian message of non-violence has permeated secular society. This concern for victims first expressed in the Christian scriptures and brought to fulfillment in the person of Jesus Christ now "dominates the planetary culture in which we live. ${ }^{31}$ Yet, ironically, many atheists today reject Christianity because of its history of violence toward innocent victims. ${ }^{32}$ Many people today fail to realize the Christian origins of a moral value that itself justifies the rejection of Christianity. It is also a moral value that serves as the foundation for much of the modern moral order. What are now widely considered secular values (e.g. equality, democracy, human rights) have been unmoored from their religious origins and falsely understood as strictly humanist values. Even in the rejection of Christianity, they are affirming what Christianity has wrought.

\footnotetext{
${ }^{27}$ Ibid., 196-199.

${ }^{28}$ Girard, Things Hidden Since the Foundation of the World, 182-189.

29 James G. Williams, Introduction, in Girard, I See Satan Fall Like Lightning, xix.

${ }^{30}$ Girard, Things Hidden since the Foundation of the World, 218-219.

${ }^{31}$ Girard, I See Satan Fall Like Lightning, 178.

32 Ibid., 180.
} 
Given Girard and Taylor's analysis of human culture, it is not surprising that so many people in the north Atlantic societies would feel the cross pressures identified above. As Taylor states, "our modern culture is restless at the barriers of the human sphere." 33 Even if the traditional idea of God is dead, Taylor still identifies a paradoxical phenomenon of an "immanent transcendence" that seeks fulfillment outside of the self, even if not strictly in spiritual forces. As Girard points out, many people seek this immanent transcendence in a globalized moral order grounded in the dignity of the human person. What is clear is that "our age is very far from settling into a comfortable unbelief., 34

\section{The Millennials in the United States}

To begin our look at the Millennial generation, we first must look broadly at generational studies. What does it mean to identify Millennials as a "generation"? Far from being speculation, generational studies detect key environmental and cultural factors which have affected certain populations during their most formative (i.e. younger) years. ${ }^{35}$ Additionally, many generational studies also look at the number of live births per year in order to demarcate the beginning dates of successive generations. ${ }^{36}$ While both factors influence generational studies, authors tend to emphasize one factor over another. ${ }^{37}$

\footnotetext{
33 Taylor, 726 .

${ }^{34}$ Ibid., 727.

${ }^{35}$ Ron Zemke, Claire Raines and Bob Filipczak, Generations at Work: Managing the Clash of Veterans, Boomers, Xers, and Nexters in Your Workplace (New York: New York: AMACOM, 2000), 4.

${ }^{36}$ In 1980 the number of live births increased to above 3.6 million and peaked at 4 million live births per year between 1989-2000. This increase in births did not end at that time, but demographers do not usually extend a generation beyond twenty years. Thom S. Rainer and Jess W. Rainer, The Millennials: Connecting to America's Largest Generation (Nashville, Tenn: B\&H Pub. Group, 2011), 3.

${ }^{37}$ Ibid., 13. It is important to note that the increasingly fast pace of technological change has suggested to many who study generational trends that the span of a generation should be drastically reduced. People born in 1980 have a markedly different experience of the world than do those born in the late 1990's, yet both groups of people are still considered Millennials.
} 
Two important disclaimers are necessary when examining generational data. First, exceptions always exist to the general trends and characteristics of a generational group. Second, data often varies slightly from generational study to generational study, especially in terms of when each generation begins and ends. Most researchers agree, however, on five main generations in American culture: the G.I. Generation (1900-1924), the Silent Generation (19251945), the Baby Boom Generation (1946-1964), Generation X (1965-1979) and the Millennial Generation (1980-2000). ${ }^{38}$

In a recent survey of 1,200 Millennials in the United States, the authors noticed that the respondents desire peace in both the personal and social arena. Some are even so fed up with shrill debates that they refuse to watch news channels. ${ }^{39}$ The Rainers report:

Though the Millennials in our study did not mention the Rodney King event, most of them did use words similar to this: "Can we all just get along?" The Millennials are weary of the fights in our nation and world. They are tired of the polarization of views. They avoid the high-pitched shouts of opposing political forces. They are abandoning churches in great numbers because they see religion as divisive and argumentative. ${ }^{40}$

This desire seems closely tied to the Millennial experience of family life, in particular, their unfortunate experiences with divorce. The Rainers describe an interview with a young Millennial:

I am determined to hold my family together,' Jayne Anne told us with resolve. 'I know marriage takes a lot of work. I know it means I have to sacrifice self for my husband and children. But I will do it. I am doing it. Nothing is more important to me than holding my family together. ${ }^{41}$

In fact, this desire to succeed in marriage and family life yields another surprising reflection from the Rainer survey: "They told us that they would like to learn from people who have long-term

\footnotetext{
${ }^{38}$ Rainer and Rainer, 9-11.

${ }^{39}$ Ibid., 157.

${ }^{40}$ Ibid. 153.

${ }^{41}$ Ibid. 155.
} 
successful marriages. In fact, 91 percent held these people up as their heroes and their life examples." ${ }^{42}$ For many Millennials, the root of a healthy marriage — or any relationship —is respect: $97 \%$ said they respect others who respect them. ${ }^{43}$ Respect is important to this generation. In summary:

"Violence is all around [Millennials] — on the Internet, on TV and videos, at the movies... Many youngsters start their normal day by passing through the metal detectors on their way to school. The spate of schoolyard shootings beginning in 1997 had a tremendous impact on teens and preteens... Our best and educated guess is that violence will become their cause celebre. ${ }^{44}$

Violence is one of those cultural and historical forces that distinctly characterize this generation.

One only needs to think of $9 / 11$ and its subsequent wars to realize this generation is reacting to a world permeated with violence and division. It is not surprising that many believe this generation will be the next peacemakers of our society.

Millennial spirituality could perhaps be summed up in four words: "spiritual but not religious." As the Rainers' study confirms, nearly 75\% call themselves “spiritual but not religious." ${ }^{45}$ However, 65\% expressed a "broadly Christian preference." ${ }^{46}$ When asked to rank spirituality among the most important features of their life, Millennials classified "spiritual matters" as sixth out of the following ten categories: family (61\%), friends (25\%), education (17\%), career/job (16\%), spouse/partner (13\%), spiritual matters $(13 \%)$, finances $(12 \%)$, happiness $(12 \%)$, raising kids $(11 \%)$, health $(10 \%) .{ }^{47}$ In terms of religious identification, the Rainers write:

\footnotetext{
42 Ibid. 155.

${ }^{43}$ Ibid. 158 .

${ }^{44}$ Zemke, Raines and Filipczak, Generations at Work : Managing the Clash of Veterans, Boomers, Xers, and Nexters in Your Workplace, 134.

${ }^{45}$ Rainer and Rainer, 243.

${ }^{46}$ Ibid. 229.

${ }^{47}$ Ibid. 229.
} 
...surprisingly, atheism (God does not exist) was the religious preference of 6 percent. Agnosticism (uncertain or doubtful that God exists) was selected by 8 percent. And 14 percent had no preference at all. Those three categories total 28 percent. Nearly three out of ten Millennials have moved completely away from certain beliefs about God. ${ }^{48}$

The Rainers dug deeper and discovered that exactly $50 \%$ of those surveyed said they prayed once a week or more, $38 \%$ indicated they prayed rarely or never and $24 \%$ pray with others. ${ }^{49}$ In terms of attendance at church services, $65 \%$ rarely or never attend religious services and $24 \%$ attend at least once a week. ${ }^{50}$ When it comes to those who read the Bible or other sacred writings: $21 \%$ read it once a week or more, $12 \%$ less frequently and $67 \%$ rarely or never read the Bible. ${ }^{51}$ Many Millennials have personal spiritual practices, though institutional religion as embodied by a church is generally seen as irrelevant (a whopping 70\% of Millennials agree with this). ${ }^{52}$ But at the same time, over half of Millennials report that a commitment to Jesus is personally important and half of them pray at least once per week. These are all positive traits that the Christian churches can build upon. Contrary to popular belief, young people are not abandoning the faith, they are abandoning our churches. We must find out why and begin to address this disconnect between personal spirituality and institutionalized, communal embodiment of that spirituality.

In another study in 2008, Christian Smith found similar data. ${ }^{53} \mathrm{He}$ found that $85 \%$ of the respondents he could classify from "spiritually open" to "committed traditionalists," while only

\footnotetext{
${ }^{48}$ Ibid. 231.

${ }^{49}$ Ibid. $235-236$.

${ }^{50}$ Ibid. 236.

${ }^{51}$ Ibid. 239. The numbers are similar when asked how frequently the meet with others to study the Bible or another sacred text: $15 \%$ once a week or more, $6 \%$ less frequently, $79 \%$ rarely or never.

${ }^{52}$ Ibid. 244.

${ }^{53}$ Christian Smith, Souls in Transition : The Religious and Spiritual Lives of Emerging Adults (Oxford: Oxford University Press, 2009), 3-4. This study followed group of young Millennials since 2005 when they were 13-17 years old (sample size 3,290 ). In 2008, they surveyed 2,458 of the original respondents who were then 18-24 years old.
} 
$10 \%$ were irreligious and hostile to religion. ${ }^{54}$ However, of that $85 \%$, only $15 \%$ were committed to a religious community, and most described themselves as indifferent to religion. ${ }^{55}$

Furthermore, most viewed all religions as relatively good and identified making good people as a religion's primary mission. ${ }^{56}$ A minority of those interviewed were quite skeptical of religion and viewed many religious adherents as hypocritical and elitist. ${ }^{57}$ Finally, according to Smith, many emerging adults today lack a great deal of conviction and direction. They are immersed in a society in which truth is relative and historically conditioned. ${ }^{58}$ They are representative of the people who are easily buffeted by the religious and cultural cross-currents identified by Taylor.

Finally, Putnam and Campbell's analysis of religion in America can be helpful for a general understanding of the sociological landscape. Although they did not break the data down into generational categories, much of what they say is helpful for understanding how religion unites and divides us in this country. For one thing, while $83 \%$ of Americans report belonging to a religion, a full $17 \%$ reported their religion as "none" in $2006 .{ }^{59}$ The only religious traditions with more adherents were evangelical Protestants (30\%) and Catholics (23\%). Clearly, many more Americans than in the past are disaffiliating themselves from organized religion. In this respect, at least, they are following the trend of the younger Millennial generation.

More interestingly, however, are Campbell and Putnam's analysis of religious polarization and diversity in the United States. The United States should be a "tinderbox for a religious conflagration" given its high rates of both religious diversity and religious devotion. ${ }^{60}$

\footnotetext{
${ }^{54}$ Ibid., 294.

${ }^{55}$ Ibid., 294,145.

${ }^{56}$ Ibid. 146-148.

${ }^{57}$ Ibid., 161.

${ }^{58}$ Ibid., 292-294.

${ }^{59}$ David E. Campbell and Robert D. Putnam, American Grace : How Religion Divides and Unites Us (New York, NY: Simon \& Schuster, 2010), 7,17.

${ }^{60}$ Ibid., 494.
} 
A full $72 \%$ of Americans agreed that "America is divided along religious lines," with $46 \%$ strongly agreeing. ${ }^{61}$ In their analysis they also found that the American religious scene is not simply one of good feelings between adherents of different religious traditions. The three smallest religious traditions in the United States-Mormon, Buddhist and Muslim—were also the most unpopular and viewed quite negatively by people outside of those religious groups. ${ }^{62}$ The authors also found that great tension existed between religious and non-religious people, with a high percentage of religious people reporting that non-religious people were intolerant and selfish (and vice-versa for non-religious people) ${ }^{63}$ However, the authors also discovered that religious bridging frequently occurred through friendships and marriages between people of different faiths ${ }^{64}$ As one might expect, having diverse social networks led to more positive assessments of specific religious groups.

We can draw a number of general conclusions from this data. Millennials are generally repulsed by a perceived prevalence of division within society and religious groups. They generally view religious institutions as irrelevant to their lives. However, most Millennials also report being spiritually open, though they lack any clear religious convictions or a uniform understanding of what that means. Most Millennials are indifferent toward religious groups rather than openly hostile. Presumably, this is because, like the rest of the nation, diverse social networks tend to favor more positive assessments of people who belong to other religions. Unlike the rest of the population, however, many more Millennials report that they do not belong to a religious tradition (75\%) compared to $83 \%$ of the American population that does report belonging to a religious tradition.

\footnotetext{
${ }^{61}$ Ibid., 495.

${ }^{62}$ Ibid., 505.

${ }^{63}$ Ibid.,499-500.

${ }^{64}$ Ibid., 526-534.
} 


\section{Evangelizing the Millennial Generation}

One thing that is very clear is that the religious make-up of the United States is increasingly pluralistic. When compared to its European counterparts, the United States has historically been religiously pluralistic, though Protestantism has tended to dominate the religious landscape. However, the number of people who report not belonging to a religion is steadily increasing, with the young adults of today reporting the highest rates of religious disaffiliation. This context must inform how Christianity understands its mission in the United States today.

Boeve examined the increasingly secular and pluralistic context in Europe and drew some conclusions that are applicable to the United States context as well. First, we must intentionally choose if the relationship between the modern world and Christian faith will be one of "continuity and dialogue" or "discontinuity and mutual exclusion." 65 While coming down on the side of the former option, Boeve offers a model of theological "interruption" that preserves continuity while also offering some discontinuity at the same time, an approach that falls somewhere between a bridge and a rupture. ${ }^{66}$ Unlike in the past, when the context was religion versus secularism, one could rely upon a generally univocal understanding of terms such as rationality and humanity, truth and justice. However, with the advent of a plurality of religious and non-religious perspectives, these terms only have specific meanings from within their particular narratives. ${ }^{67}$ Thus, the particularity of the Christian narrative can challenge other narratives that, for example, functionalize religion by viewing it merely as an effective vehicle of

\footnotetext{
${ }^{65}$ Lieven Boeve, God Interrupts History: Theology in a Time of Upheaval (New York: Continuum, 2007) , 7.

${ }^{66}$ Ibid., 42-43.

${ }^{67}$ Ibid., 43.
} 
meaning for those who need such a thing. ${ }^{68}$ By respecting the "irreducible particularity" of its narrative, Christianity can remind other particular narratives to do the same. Furthermore, Boeve retrieves the important understanding that the incarnation is a particular event and that salvation history is series of particular interactions between God and humanity. ${ }^{69}$

There is also an ad extra dimension to Boeve's theology of interruption. By appreciating the irreducible particularity of all religious narratives, we realize that every narrative is like learning a language because it "presupposes grammar, vocabulary, competence, and familiarity." ${ }^{70}$ The encounter with the Other forces all religions to acknowledge their particularities and to acknowledge the fact that communication between them will always be hampered by the lack of a common language. This realization forces religions to engage in dialogue and invitation rather than argumentation and polemical speech. There is also an ad intra dimension that forces theology to recontextualize itself toward its own adherents. The encounter with the Other can often force a rethinking of one's own theology, as happened, for example, at Vatican II when the Council fathers were forced to rethink their relationship to non-Christian religions and to the Jewish people.

Girard's religious anthropology is very congruent with Boeve's theological method of interruption. Girard does not attempt to conflate Christianity with other historical religions, but instead respects Christianity's particular narrative as unique and decisive for the history of humanity. The particular narrative of God's dealings with Israel provides the foundation of Christ's fulfillment in the Gospels. Job recognizes he is a scapegoat and cries to God for help. ${ }^{71}$

\footnotetext{
${ }^{68}$ Ibid., 44-45.

${ }^{69}$ Ibid., 46-47.

${ }^{70}$ Ibid., 52.

${ }^{71}$ Williams in René Girard, I See Satan Fall Like Lightning, xviii.
} 
The prophets denounce the shedding of blood and the unjust exploitation of the poor. ${ }^{72}$ The Suffering Servant of Isaiah 53 is a prefiguring of the innocent victim, Jesus. ${ }^{73}$ God interrupted the history of Israel to call his people to a different way of life.

Then Jesus interrupted the world that everybody had always known. The disciples instinctively thought in terms of mimetic competition and jockeyed for power, but Jesus preached an alternative kingdom of peace and justice. Jesus' death and resurrection interrupted the expectations of his disciples and forced them to reconsider Jesus' identity as one who was also divine. Furthermore, the crucifixion and resurrection interrupted the mechanisms of violence for the whole world. It is precisely in the unjust crucifixion of Jesus that the scapegoat mechanism within all religions and all cultures is revealed. It was necessary to the unmasking that they unjustly sacrifice a victim who was not himself tainted by the same cycle of violence. Nobody can participate any longer in sacred violence without understanding that the victim is really innocent and the persecution is unjust. Theological interruptions can jar people awake, they can make people see things with new eyes.

Theological interruptions also have an ad intra dimension that can jar people awake who adhere to the religion. Girard acknowledges that many Christians do not realize how they are still implicit in the scapegoat mechanism. Many people today think it is acceptable, for example, to persecute those who persecute innocent victims; they do not realize that such behavior only perpetuates the cycle of violence that Jesus came to stop. The Gospels provide a narrative that can interrupt people's behaviors and cause them to rethink what they are doing.

Similarly, Girard labels as the "anti-Christ" the forces within our own time that speak about bringing the "peace and tolerance that Christianity promised but has failed to deliver."

\footnotetext{
${ }^{72}$ Ibid., xviii.

${ }^{73}$ Depoortere, 44.
} 
Yet, as pointed out already, it is precisely the concern for victims and the promotion of peace and tolerance that originated with Christianity. What comes across as a timeless moral imperative was not always so. Yet it is precisely this prevalence of Christian principles in society that is proof that Christianity is succeeding in its goal to end the victim mechanism. Christianity has interrupted and turned the world upside down, and it has done this so subtly that nobody realizes they are upside down.

In a world of expressive individualism (to use Taylor's term), in which all choices are but expressions of preferences in a free market of choices, it can appear that religion is just one choice among many. ${ }^{75}$ In a pluralistic world, one can choose to be religious, to be non-religious, to be agnostic or to be something in between. As demonstrated by the sociological data, the Millennials are picking and choosing the parts of religion that appeal to them. It is expressive individualism to its maximum intensity.

But Girard reminds us that one's choice of religion matters because religion has existential import. The Christian narrative is not one narrative among others; it is the narrative that has unmasked all of the others. Christianity has interrupted history and changed the rules of the game. As Boeve says, "Christians are bearers of the subversive, dangerous memory of the suffering, death and resurrection of Jesus Christ." ${ }^{, 76}$ This narrative matters for the lives of believers and for the life of the world.

As Boeve points out, the detraditionalization of the world has forced people to construct their own identities. ${ }^{77}$ No longer does society, or the culture in general, supply its members with a narrative. This is both a scary and full of opportunity. Now Christianity can enter into a

\footnotetext{
${ }^{74}$ René Girard, I See Satan Fall Like Lightning, 181.

${ }^{75}$ Taylor, 505.

${ }^{76}$ Boeve, 203.

${ }^{77}$ Ibid., 204.
} 
dialogue with the Other and offer an invitation to others. Millennials as a whole are without much spiritual direction. They are adrift in the world, seeking spiritual sustenance but at the same time wary of traditional religious institutions. Girard's anti-sacrificial narrative can provide an appealing face to Christianity that is both anti-violence and full of existential import. It is a narrative that matters and calls forth an equally serious response.

Girard's anthropology also has definite apocalyptic overtones. Although Jesus initiated the unmasking of the sacrificial system, his mission is still unfolding in the history of the world. Many people view Christianity as one of the main persecutors of innocent victims, and indeed the Crusades, the wars of religion and the Reformation perpetuated the scapegoat mechanism. But the seriousness of Jesus' mission also interrupts time and brings time to a crisis point. Jesus' interruption in the past continues into the present and demands a response. Will we perpetuate the sacrificial mechanism that unjustly put the Son of God to death, or will we side with God and his Kingdom of peace and justice? As Boeve states, "apocalypticism calls for the radical temporalization of the world, with a radical awareness of the irreducible seriousness of what occurs in the here and now." ${ }^{, 78}$ Apocalypticism is about the future, but it is also about the present. It is not about linear progression of time, but about a gathering of all time into God's present. The incarnation of Jesus is a present reality for the believer and radically shifts his or her perspective.

One of the difficulties of Girard's narrative is that the scapegoat mechanism is so ingrained into humanity's cultures. It remains hidden, even in a world attuned to the suffering of the innocent, and thus is difficult to unearth in its many subtle disguises. Yet Girard's antisacrificial lens can reveal a great deal of violence in our culture that previously has gone unnoticed. As Girard says, the persecutors even hide their scapegoating from themselves,

\footnotetext{
${ }^{78}$ Ibid., 197.
} 
especially if the violence is psychological rather than physical. ${ }^{79}$ Yet for Millennials concerned about a world of nuclear weapons, melting ice caps and the worldwide divide between the rich and the poor, Girard's insight can be revealing. How often the poor are forgotten in our world, victims of neglect by the industrialized world, and metaphorically sacrificed on the altar of economic efficiency? One can see the stark imbalances of power in the many wars and armed conflicts erupting around the world. This too is a metaphorical sacrifice of the innocent victim when civilians are killed in the name of justice and peace. Girard's insight of Jesus as the antisacrifice can provoke Christianity to see how it is complicit in the subtle ways our society continues to sacrifice innocent victims for the community's greater good. In the Rainer study, $77 \%$ of Millennials affirmed the statement, "I am motivated to serve others in society." 80 As a group, the Millennials are very other-centered and concerned about the wider world and would be attracted to a Christianity with a Girardian spin.

Girard and Taylor present a particular Christian narrative within a particular secular world. It is a world dominated by expressive individualism in which individual preference is dominant and all choices are equally meaningful. However, the transcendent aspect of the human experience is never completely hidden from view, despite the constrictions of society's immanent frame. Girard's insight into the unjust sacrificial foundations of human culture provides a portrait of Jesus as the anti-sacrificial who came to end all sacrifices. This message can be very attractive to young people today who are wary of the violence and division in the world. The Christian narrative, especially as experienced through a Girardian filter, demands a committed and meaningful response. It is a narrative that portrays God as one who has interrupted culture and time and shaken people from their stupor. In a pluralistic world, this is a

\footnotetext{
${ }^{79}$ Girard, I see Satan, 157.

${ }^{80}$ Rainer and Rainer, 117.
} 
narrative that matters for its adherents and for the larger world. It forces people to choose between the world of sacrifice or the Kingdom of God and to do so within an apocalyptic framework that demands a decision now. The particularity and urgency of the Christian narrative is anything but meaningless, and the seriousness of Christianity's anti-sacrificial message can appeal to a younger generation that seeks transcendence, meaning and peace. 